\title{
Structural and Theoretical Investigations, Hirshfeld Surface Analyses, and Cytotoxicity of a Naphthalene-Based Chiral Compound
}

\author{
Saud I. Al-Resayes, Mohammad Azam,* Agata Trzesowska-Kruszynska, Rafal Kruszynski, \\ Saied M. Soliman, Ranjan K. Mohapatra, and Zahid Khan
}

Cite This: ACS Omega 2020, 5, 27227-27234

Read Online

ABSTRACT: A novel Schiff base compound derived from the condensation of 2-hydroxy-1-naphthaldehyde with $(1 S, 2 S)$-(-)-1,2-diphenylethylenediamine in 2:1 $\mathrm{M}$ ratio was reported and investigated by elemental analyses, Fourier transform infrared and NMR spectroscopic studies, and single-crystal X-ray crystallography. Hirshfeld surface analyses were also carried out to measure the various intermolecular contacts controlling the supramolecular topology, suggesting the $\mathrm{H} \cdots \mathrm{O}(7.6 \%)$ contacts to be the most significant interactions, whereas the $\mathrm{H} \cdots \mathrm{H}(48.9 \%)$ and $\mathrm{C} \cdots \mathrm{H}(40.2 \%)$ interactions are less-significant. The data obtained from the energy calculations revealed the structure observed experimentally to be the most stable isomer and its energy being lower by $18.0441 \mathrm{kcal} / \mathrm{mol}$ than the less stable one. Density functional theory calculations were also carried out to analyze the natural charges, reactivity descriptors, and different intramolecular charge transfer interactions. The in vitro anticancer activity of the compound was evaluated by MTT assays against human colorectal cancer cells, HT29 and SW620. The results showed that the compound has potential anticancer activity against these cells lines.

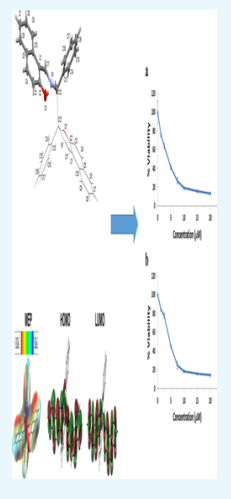

\section{INTRODUCTION}

Despite the significant advances, cancer, which is caused by the unregulated proliferation of abnormal cells, remains one of the leading causes of death worldwide. ${ }^{1,2}$ Over the years, the clinical success of cisplatin and its second-generation analogues encouraged researchers to discover new drugs with minimal side effects and maximal curative potential. ${ }^{3,4}$ However, the use of cisplatin is limited because of severe toxic side effects including nephrotoxicity, neurotoxicity, and ototoxicity. Low water solubility, instinct, and acquired resistance exhibited in various types of cancers are also valid problems prohibiting the usage of cisplatin. ${ }^{3-5}$ For these reasons, the development of new potential chemotherapeutic drugs with high efficacy and low toxicity is a great challenge in modern cancer research. ${ }^{6}$

Over the years, Schiff bases have received enormous significance in medicinal chemistry because of their biological, pharmacological, and antitumor properties, chelating behavior, preparative accessibilities, structural varieties, and varied denticities. $^{7-9}$ It is shown that the presence of the $>\mathrm{C}=\mathrm{N}$ functional group is supposed to be responsible for medicinal properties exhibited by Schiff bases. ${ }^{10}$ Furthermore, there are several reports that Schiff bases have the capability of stabilizing oxidation states of various metal ions and therefore play an extensive role in various catalytic reactions. ${ }^{11}$ However, the geometry of Schiff bases largely depends on the diamine structural unit, nature of the ancillary ligand, and central metal ion. $^{12}$
We are reporting here a novel Schiff base compound derived from 2-hydroxy-1-naphthaldehyde and (1S,2S)-(-)-1,2-diphenylethylenediamine in 2:1 $\mathrm{M}$ ratio. There are several reports published on the synthesis of the studied compound in the literature. ${ }^{13-16}$ In our work, we discuss the never previously reported crystal structure of the compound, enriched by elemental analyses and spectroscopic studies [Fourier transform infrared (FT-IR) and NMR]. However, we used the methods of quantum crystallography [density functional theory (DFT) calculations and Hirshfeld surface analyses] to provide even better insights into the properties of the structure. We conclude our investigation with an analysis of potential anticancer activity against the colorectal cancer cells HT-29 and SW620. Results suggest potential activity against both types of the studied cancer cells.

\section{RESULTS AND DISCUSSION}

All atoms of the studied Schiff base compound [Figure 1] occupy general positions, but the 2 -fold rotation axis going through the midpoint of the ethylenediamine $\mathrm{C}-\mathrm{C}$ bond causes one molecule to be located in two asymmetric units.

Received: July 14, 2020

Accepted: September 29, 2020

Published: October 12, 2020 


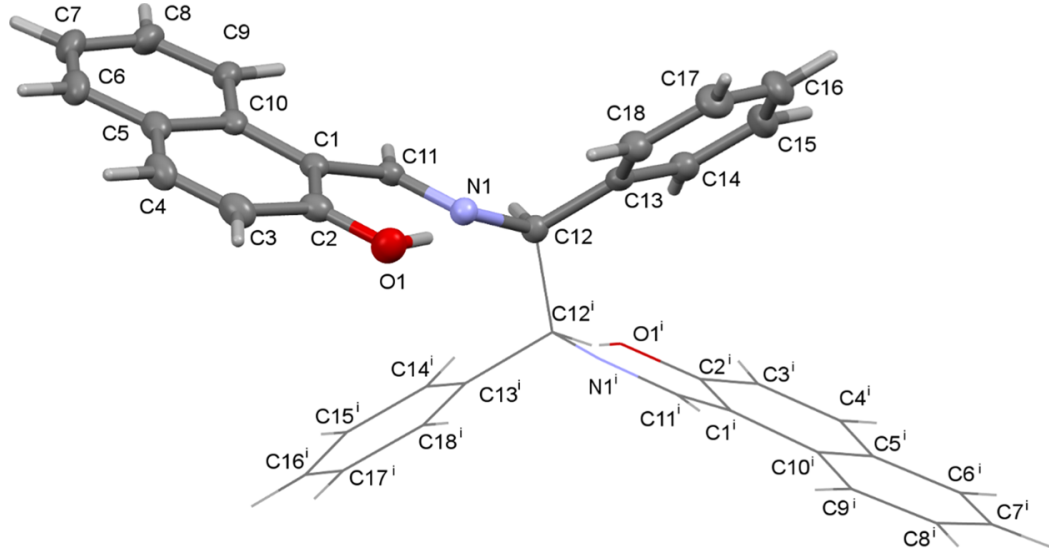

Figure 1. Molecular structure of the compound with $50 \%$ probability of displacement ellipsoids.

The (2-hydroxy-1-naphthylmethylene)amine moieties are close to planarity (Table 1) and the twist of the molecule

Table 1. Selected Structural Data of the Compound $\left[\AA,^{\circ}\right]^{a}$

$\begin{array}{ll}\mathrm{C} 11-\mathrm{N} 1 & 1.2962(19) \\ \mathrm{N} 1-\mathrm{C} 12 & 1.4567(19) \\ \mathrm{O} 1-\mathrm{C} 2-\mathrm{C} 1-\mathrm{C} 11 & 7.1(2) \\ \mathrm{C} 2-\mathrm{C} 1-\mathrm{C} 11-\mathrm{N} 1 & -5.5(2) \\ \mathrm{C} 1-\mathrm{C} 11-\mathrm{N} 1-\mathrm{C} 12 & 171.30(13) \\ \mathrm{C} 11-\mathrm{N} 1-\mathrm{C} 12-\mathrm{C} 12^{\mathrm{i}} & -119.54(14) \\ \mathrm{N} 1-\mathrm{C} 12-\mathrm{C} 12^{\mathrm{i}}-\mathrm{N}^{\mathrm{i}} & -73.5(2)\end{array}$

${ }^{a}$ Symmetry transformations used to generate equivalent atoms: (i) $-x$ $+2, y,-z$.

occurs only within ethylenediamine linkage (about its three bonds, two $\mathrm{C}-\mathrm{N}$, and one $\mathrm{C}-\mathrm{C}$; Table 1 ). The analysis of dihedral angles (Table 1) shows that the molecule adopts the anticlinal-synclinal-anticlinal conformation of the methylene-ethylenediamine bridge. The comparison of $\mathrm{C}-\mathrm{N}$ bond lengths shows that the double bonds are fully localized within naphthylmethyleneamine moieties. Both chiral centers possess $S$ configuration. The terminal naphthalene ring systems are inclined at $40.21(4)^{\circ}$, which originates from the twist of the above-described central $\mathrm{C}=\mathrm{N}-\mathrm{C}-\mathrm{C}-\mathrm{N}=\mathrm{C}$ linkage. The least squares planes calculated through all atoms of naphthyl moieties show that some of their atoms slightly deviate from the substituent plane. Observed deviations are not larger than 0.0371 (12) $\AA$ (this value was registered for the $\mathrm{C} 1$ atom) and such deviations are typical for similar compounds. ${ }^{17}$ Each molecule is internally linked by two types of hydrogen bonds (Table 2), that is, $\mathrm{O}-\mathrm{H} \cdots \mathrm{N}$ and $\mathrm{C}-\mathrm{H} \cdots \mathrm{N}$ ones. ${ }^{18}$ All these bonds form S(6) motifs of unitary graph. ${ }^{19}$ Additionally, the molecules are assembled by the intermolecular $\mathrm{C}-\mathrm{H} \cdots \mathrm{O}$ hydrogen bond (Table 2) to a supramolecular chain extending

Table 2. Hydrogen Bonds Geometry of the Compound [ $\AA$, o $]^{a}$

\begin{tabular}{lccc}
\multicolumn{1}{c}{$\mathrm{D}-\mathrm{H} \cdots \mathrm{A}$} & $d(\mathrm{D}-\mathrm{H})$ & $d(\mathrm{H} \cdots \mathrm{A}) d(\mathrm{D} \cdots \mathrm{A})$ & $\angle(\mathrm{DHA})$ \\
$\mathrm{O} 1-\mathrm{H} 1 \mathrm{O} \cdots \mathrm{N} 1$ & 0.86 & $1.712 .5328(17)$ & 157.6 \\
$\mathrm{C} 14-\mathrm{H} 14 \cdots \mathrm{O} 1^{\mathrm{ii}}$ & 0.95 & $2.483 .315(2)$ & 146.2 \\
$\mathrm{C} 18-\mathrm{H} 18 \cdots \mathrm{N} 1$ & 0.95 & $2.512 .836(2)$ & 100.3
\end{tabular}

${ }^{a}$ Symmetry transformations used to generate equivalent atoms: (ii) $-x+2, y-1,-z$. along the crystallographic [ $\left[\begin{array}{lll}0 & 1 & 0\end{array}\right]$ axis and described by the $\mathrm{C}(10)$ motif of unitary graph of the lowest degree [Figure 2]. Because of the presence of the above-described 2-fold rotation axis (going through the midpoint of the ethylenediamine $\mathrm{C}-\mathrm{C}$ bond), the intermolecular $\mathrm{C}-\mathrm{H} \cdots \mathrm{O}$ hydrogen bond forms also a $\left[\mathrm{R}_{2}^{2}(20)\right]$ motif of unitary graph of lowest degree. The formed hydrogen-bonded chains are well separated and do not assemble in a larger supramolecular structure even via the $\pi \cdots \pi$ interactions $^{20}$ (neighboring crystal net aromatic rings are distinctly nonparallel).

The ${ }^{1} \mathrm{H}$ NMR spectral findings of the studied Schiff base compound are provided in the Experimental Section and fully supported by single-crystal X-ray crystallographic data. A characteristic singlet due to the azomethine proton appears at $8.97 \mathrm{ppm}$. Another singlet due to the $-\mathrm{CH}$ proton $(-\mathrm{N}-\mathrm{CH}-$ $\mathrm{CH}-\mathrm{N}-, 2 \mathrm{H}, \mathrm{s}$ ) is found at $4.89 \mathrm{ppm}$. However, the multiplets due to aromatic protons appear at 7.01-7.81 ppm [Figure S1]. The ${ }^{13} \mathrm{C}$ NMR spectral results further confirm the ${ }^{1} \mathrm{H}$ NMR findings. The most important and characteristic signal due to azomethine carbon appears at $168.0 \mathrm{ppm}$, whereas the signals due to aromatic carbon appear at 118.9-138.7 ppm. However, the carbon signal due to $\mathrm{C}-\mathrm{O}$ appears at $161.3 \mathrm{ppm}$. The signal due to $-\mathrm{CH}-\mathrm{N}-\mathrm{N}-\mathrm{CH}-$ appears at $107.0 \mathrm{ppm}$ [Figure S2].

The characteristic azomethine vibration due to $\nu_{(-\mathrm{CH}=\mathrm{N})}$ is located at $1621 \mathrm{~cm}^{-1} \cdot{ }^{14,21}$ A strong band due to the phenolic (C-O) vibration appears at $1190 \mathrm{~cm}^{-1} \cdot 14,21$ Furthermore, vibrations due to the aromatic ring appear at 648, 1030, and $1480 \mathrm{~cm}^{-121,22}$ [Figure S3].

Hirshfeld Analysis of Molecular Packing. Various observed contacts and their percentages in the crystal structure of the studied compound based on Hirshfeld calculations are displayed in Figure 3. The packing of molecules is mainly dependent on $\mathrm{H} \cdots \mathrm{H}(48.9 \%)$ and $\mathrm{C} \cdots \mathrm{H}(40.2 \%)$ interactions and the significant $\mathrm{C}-\mathrm{H} \cdots \mathrm{O}$ interactions (7.6\%). All intermolecular contacts appearing as blue regions in the $d_{\text {norm }}$ map indicate interactions with longer distances than vdW radius sum of the interacting elements [Figure 4]. The only exception are the $\mathrm{C}-\mathrm{H} \cdots \mathrm{O}$ interactions, which appear as red spots in the $d_{\text {norm }}$ map and sharp spikes in the fingerprint plot, indicating that these intermolecular interactions have contact distances shorter $(2.347 \AA$; O1 $\cdots \mathrm{H} 14)$ than the sum of the van der Waals radii of the oxygen and hydrogen atoms [Figure 4]. As can be seen from this figure, the $d_{\text {norm }}$ maps indicate interaction distances longer than the vdW radius sum of the interacting atoms for the $\mathrm{H} \cdots \mathrm{H}$ and $\mathrm{C} \cdots \mathrm{H}$ interactions. 


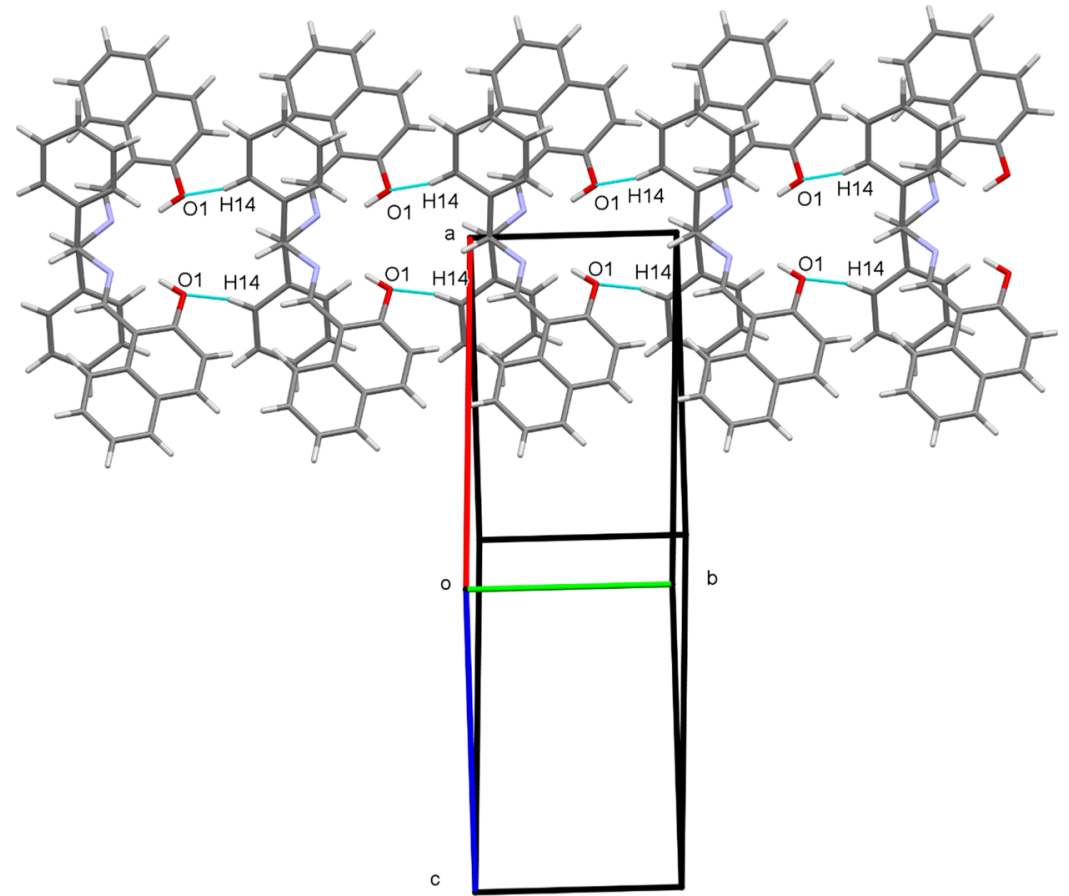

Figure 2. Part of molecular packing with $\mathrm{C} 14-\mathrm{H} 14 \cdots \mathrm{O} 1$ hydrogen bonds (forming a C $(10)$ motif along the $\left[\begin{array}{ll}0 & 1\end{array}\right]$ axis) indicated by blue lines.

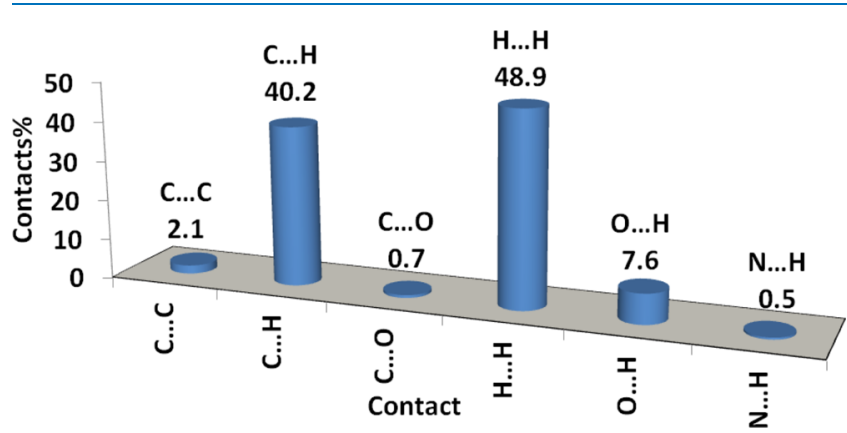

Figure 3. Intermolecular interactions and their percentages in the compound.

DFT Studies. The optimized geometry of the compound together with the structure matching between the experimental and calculated structures is presented in Figure 5. The calculated bond distances and angles compared to the experimental results are listed in Table S1 and Figure S4. However, in contrary to the X-ray structure, slight deviations in the calculated structure are likely due to the calculation in the gas phase and therefore free from the environmental effects causing the interactions with the neighboring molecules. Figure 6 reveals that the correlation coefficients between the calculated and experimental geometric parameters are high (0.9844-0.9748). The molecular structure is stabilized by two equidistance intramolecular $\mathrm{O}-\mathrm{H} \cdots \mathrm{N}$ hydrogen bonds with hydrogen-acceptor distances of $1.631 \AA$ (exp. $1.714 \AA$ ).

The calculated charges at the different atomic sites are listed in Table S2. Distribution of molecular electrostatic potential (MEP) mapped over electron density revealed that the $\mathrm{N}$ $(-0.537 e)$ and $\mathrm{O}(-0.687 e)$ sites and most of the carbon atoms have negative partial charges. However, only the $\mathrm{C}$ atoms attached to $\mathrm{N}$ or $\mathrm{O}$ are electropositive, whereas the $\mathrm{O}-$ $\mathrm{H}$ protons have the most positive partial charges $(+0.517 e)$ [Figure 7]. The calculations predicted that the studied compound is a polar molecule with a net dipole moment of 2.641 debye.

The frontier molecular orbitals, highest occupied molecular orbital (HOMO) and lowest unoccupied molecular orbital (LUMO), are important for the molecular reactivity. However, the patterns of both molecular orbitals are very similar [Figure 7] and distributed over the fused ring $\pi$-system, suggesting the HOMO $\rightarrow$ LUMO excitation of the $\pi-\pi^{*}$ transition type. The energy calculated for both the HOMO and LUMO is -5.510 and $-1.564 \mathrm{eV}$, respectively, and the energy of this transition is $3.946 \mathrm{eV}$. In this regard, the reactivity descriptors ${ }^{23-27}$ such as the ionization potential $(I)$, electron affinity $(A)$, hardness $(\eta)$, electrophilicity index $(\omega)$, and chemical potential $(\mu)$ are calculated to be $5.510,1.564,3.946,1.585$, and $-3.537 \mathrm{eV}$, respectively.

Natural Bond Orbital Analysis. Various intramolecular charge transfer (IMCT) processes arising in the studied compound with the help of second-order perturbation theory and natural bond orbital (NBO) calculations are listed in Table S3. ${ }^{28,29}$ The $\sigma-\sigma^{*}$ IMCT has stabilization energies $\left(E^{(2)}\right)$ not exceeding $5 \mathrm{kcal} / \mathrm{mol}$; therefore, these IMCT interactions are not included in this discussion. The system is stabilized by many significant $\pi \rightarrow \pi^{*}$ IMCT interactions with energy values up to $24.62 \mathrm{kcal} / \mathrm{mol}$ for the $\pi(\mathrm{C}-\mathrm{C}) \rightarrow \pi^{*}(\mathrm{C}-$ $\mathrm{N})$ IMCT interaction. The net $E^{(2)}$ value for all $\pi \rightarrow \pi^{*}$ IMCT interactions is the highest $(701.74 \mathrm{kcal} / \mathrm{mol})$. On the other hand, the system is stabilized by few number of $\mathrm{n} \rightarrow \sigma^{*}$ and $\mathrm{n}$ $\rightarrow \pi^{*}$ IMCT with a net stabilization energy of 18.49 and 85.68 $\mathrm{kcal} / \mathrm{mol}$, respectively (Table S3).

Energetics and Relative Stability. The studied compound possesses two stereogenic centers, leading to a maximum of four possible isomers. However, the optimized structures of the two energetically distinguishable isomers A and $\mathrm{B}$ are shown in Figure 8. The energies and thermodynamic parameters of these isomers, listed in Table 4, suggest that the isomer A is more stable than B by $18.0441 \mathrm{kcal} / \mathrm{mol}$ and the conversion from $\mathrm{B}$ to $\mathrm{A}$ is a thermodynamically favored process 


\section{C...H contacts}
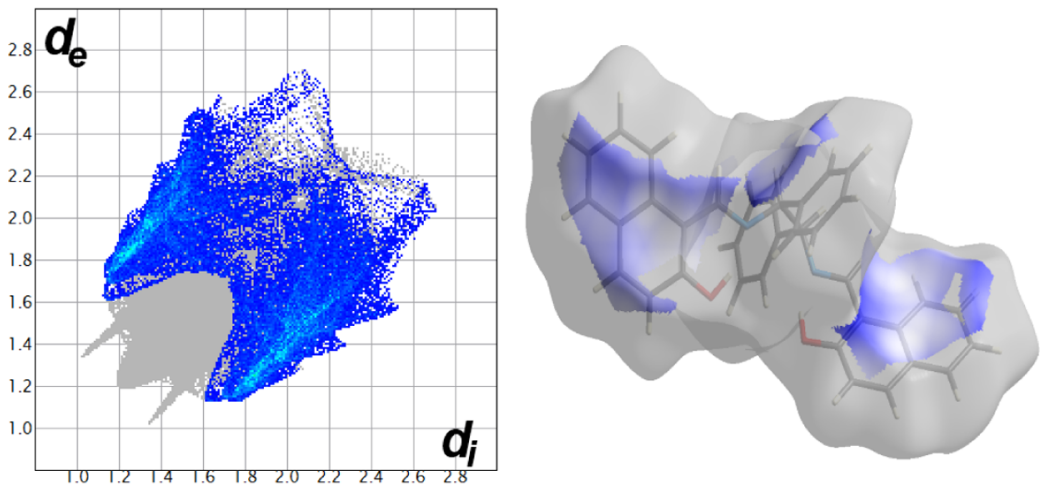

H...H contacts
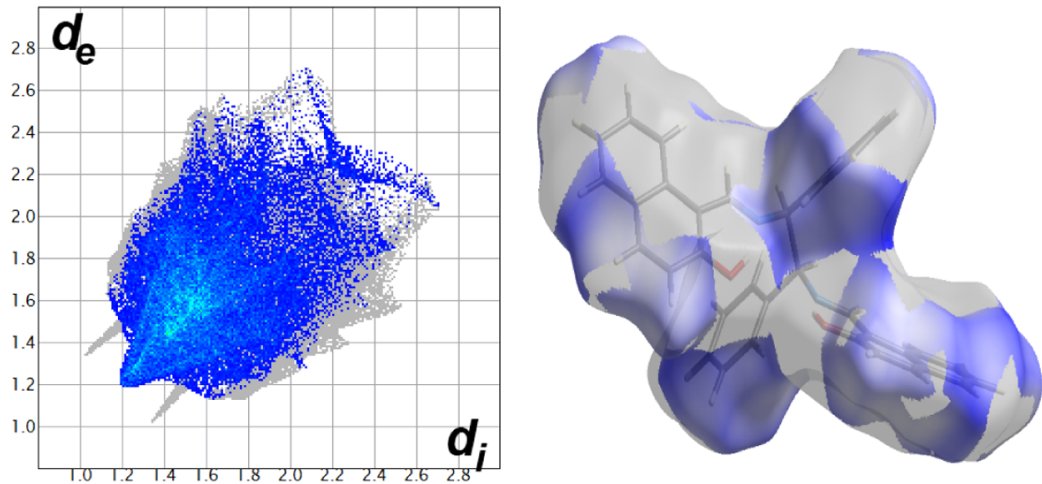

\section{O...H contacts}

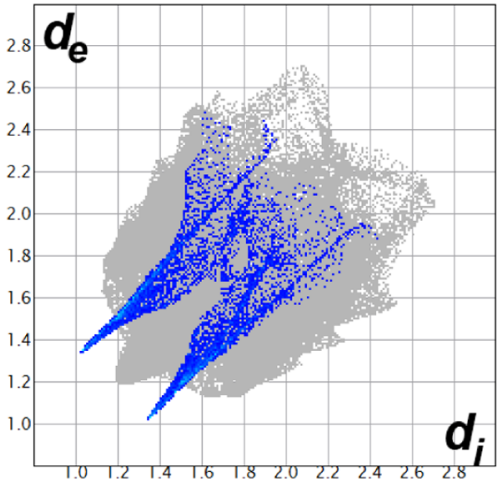

Fingerprint

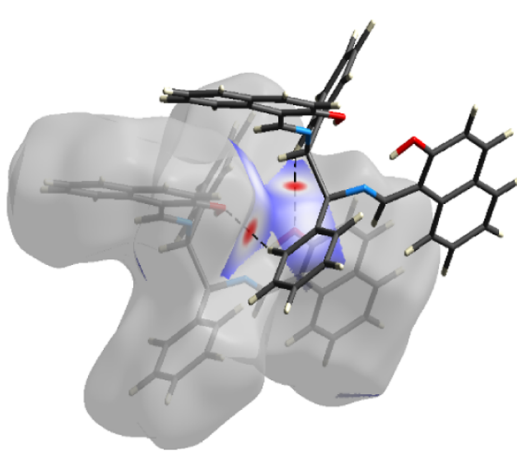

$\boldsymbol{d}_{\text {norm }}$

Figure 4. Hirshfeld surface analysis of the studied compound.
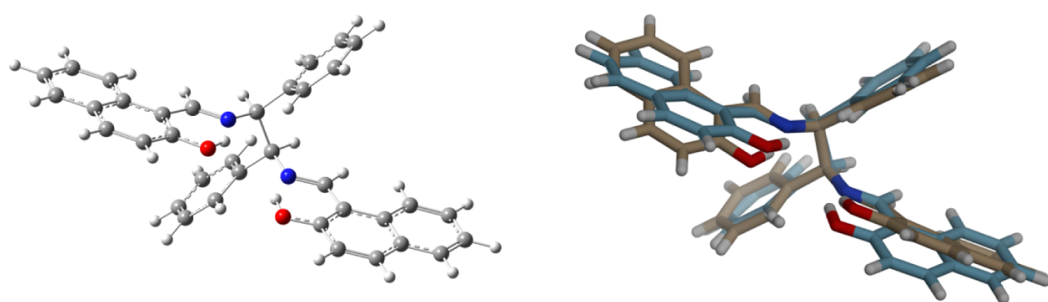

Figure 5. Optimized geometry (left) and overlapping of the optimized and experimental structures (right).

with a net Gibbs free energy change of $-19.1008 \mathrm{kcal} / \mathrm{mol}$. The extra stability of $\mathrm{A}$ is in good agreement with the reported $\mathrm{X}$-ray structure of the studied compound.

In Vitro Antitumorigenic Activity. The antitumorigenic activity of the compound was examined using MTT assay on colorectal cancer cell lines. The cytotoxic effect on HT29 and
SW620 colorectal cancer cells was monitored after exposing them to a wide range of different concentrations from 1.25 to $20 \mu \mathrm{M}$ of the compound for $24 \mathrm{~h}$. A significant decrease in cell viability was observed with increase in drug dosage in both the cancer cell lines [Figure 9]. The cell viability at the maximum tested drug concentration of $20 \mu \mathrm{M}$ for HT29 cells relative to 

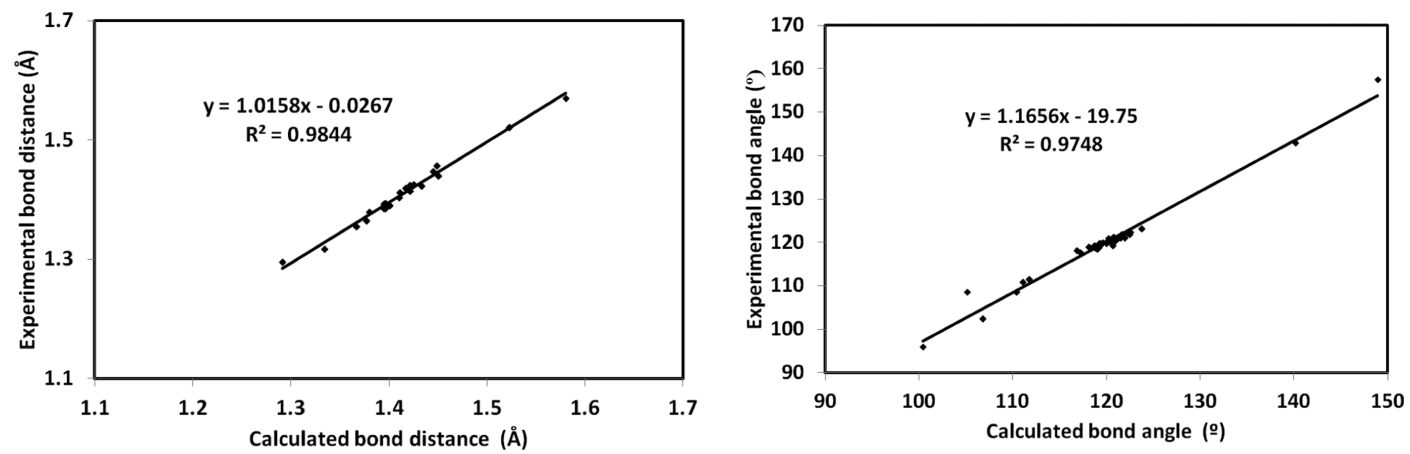

Figure 6. Straight-line correlations between the calculated and experimental geometric parameters.
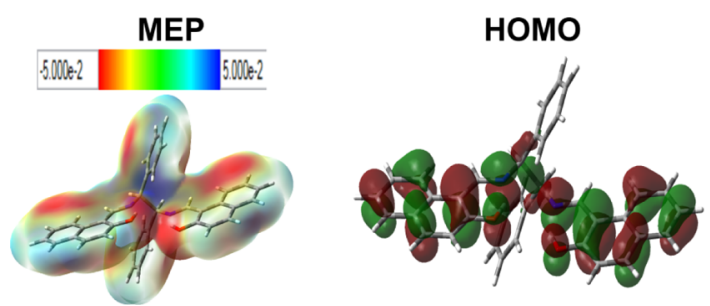

\section{LUMO}

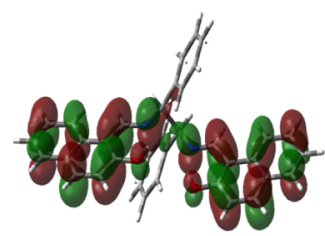

Figure 7. MEP, HOMO, and LUMO of the studied compound.

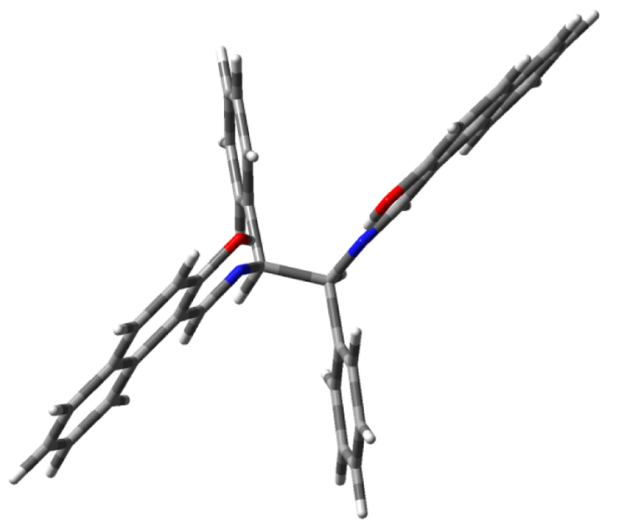

A

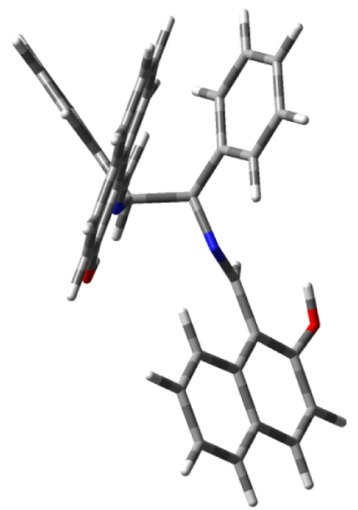

$\mathbf{B}$

Figure 8. Structure of the calculated isomers of the studied compound.

the untreated control cells decreased to $13.6 \%$ and that for SW620 cells reduced to $14.3 \%$. The $\mathrm{IC}_{50}$ for the HT29 and SW620 colorectal cancer cell lines was calculated to be 6.2 and $7.1 \mu \mathrm{M}$, respectively. These findings suggest that the compound is significantly cytotoxic and has the potential to be utilized as an antitumorigenic agent in colorectal cancer treatment.

\section{CONCLUSIONS}

We have successfully synthesized and crystallized a naphthalene-based Schiff base compound and investigated it by single-crystal X-ray crystallography and spectroscopic studies. DFT calculations were also carried out to describe electronic aspects of the compound, whereas the Hirshfeld surface analysis revealed various interactions. The compound exhibited potential anticancer activity when tested against human colorectal cancer cells, HT-29 and SW620.

\section{EXPERIMENTAL SECTION}

Materials and Methods. (1S,2S)-(-)-1,2-Diphenylethylenediamine, 2-hydroxy-1-naphthaldehyde, and other reagents were purchased from Sigma. C, H, N analyses and FT-IR and NMR studies were performed using an Elementar Varrio EL analyzer, PerkinElmer 621 spectrophotometer, and JEOL spectrometer at 400 and $100 \mathrm{MHz}$ in $\mathrm{CDCl}_{3}$, respectively.

Synthesis of the Naphthalene-Based Schiff Base Compound, (1S,2S)-1,2-Diphenyl- $N, N^{\prime}$-bis[(E)-2-hydroxynaphthalen-1-ylmethylidene]ethane-1,2-diamine. A methanolic solution of $(1 S, 2 S)-(-)-1,2$-diphenylethylenediamine $(100 \mathrm{mg}, 0.471 \mathrm{mmol})$ was added in a solution of 2 hydroxy-1-naphthaldehyde $(162.2 \mathrm{mg})$ in $1: 2 \mathrm{M}$ ratio in the same solvent followed by stirring for $10 \mathrm{~h}$ at room temperature. A yellow-colored product was formed, which was filtered off and dried. The product was dissolved in dichloromethane and produced beautiful crystals upon diffusion in $n$-pentane.

Color: yellow; Analytical Calcd for $\mathrm{C}_{36} \mathrm{H}_{28} \mathrm{~N}_{2} \mathrm{O}_{2}$ (calcd): C, 83.05; H, 5.42; N, 5.38; (Found): C, 83.00; H, 5.38; N, 5.35; ${ }^{1} \mathrm{H} \mathrm{NMR}\left(\mathrm{CDCl}_{3}\right): \delta(\mathrm{ppm}) 8.97(\mathrm{~s}, 2 \mathrm{H},-\mathrm{CH}=\mathrm{N}), 6.36-$ 
Table 3. Crystal and Structure Refinement Data of the Studied Compound

\begin{tabular}{|c|c|}
\hline compound & Schiff base compound \\
\hline empirical formula & $\mathrm{C}_{36} \mathrm{H}_{28} \mathrm{~N}_{2} \mathrm{O}_{2}$ \\
\hline formula weight & 520.60 \\
\hline crystal system, space group & monoclinic, $C 2$ (no. 5) \\
\hline \multirow{4}{*}{$\begin{array}{l}\text { unit cell dimensions }[\AA \text {, } \\
\text { deg] }\end{array}$} & $a=20.8290(5)$ \\
\hline & $b=6.8342(2)$ \\
\hline & $c=10.2080(3)$ \\
\hline & $\beta=112.556(2)$ \\
\hline volume $\left[\AA^{3}\right]$ & $1341.95(7)$ \\
\hline $\begin{array}{l}Z \text {, calculated density } \\
{\left[\mathrm{mg} / \mathrm{m}^{3}\right]}\end{array}$ & $2,1.288$ \\
\hline$F(000)$ & 548 \\
\hline crystal size $[\mathrm{mm}]$ & $0.119,0.113,0.098$ \\
\hline $\begin{array}{l}\theta \text { range for data collection } \\
\text { [deg] }\end{array}$ & 4.597 to 70.205 \\
\hline index ranges & $-24 \leq h \leq 25,-8 \leq k \leq 8,-12 \leq l \leq 12$ \\
\hline reflections collected/unique & $7396 / 2457\left[R_{(\mathrm{int})}=0.0861\right]$ \\
\hline completeness [\%] & $99.9\left(\right.$ to $\left.\theta=70^{\circ}\right)$ \\
\hline data/restraints/parameters & $2457 / 1^{a} / 181$ \\
\hline Friedel reflections coverage & 0.760 \\
\hline Friedel reflections fraction & 0.917 \\
\hline Flack parameter & $0.02(5)$ \\
\hline goodness-of-fit on $F^{2}$ & 1.047 \\
\hline final $R$ indices $[I>2 \sigma(\mathrm{I})]$ & $R_{1}=0.0259, \mathrm{w} R_{2}=0.0701$ \\
\hline$R$ indices (all data) & $R_{1}=0.0263, w R_{2}=0.0706$ \\
\hline $\begin{array}{l}\text { largest diff. peak and hole } \\
{\left[\mathrm{e} / \AA^{3}\right]}\end{array}$ & $0.173,-0.141$ \\
\hline${ }^{a}$ Floating origin restraint. & \\
\hline
\end{tabular}

Table 4. Energies and Thermodynamic Parameters in au of the Isomers $A$ and $B$

$\begin{array}{lll}\text { parameter } & A & B \\ E & -1648.7165 & -1648.6878 \\ \mathrm{ZPVE}^{a} & 0.5466 & 0.5466 \\ E_{\text {tot }} & -1648.1699 & -1648.1412 \\ H & -1648.1372 & -1648.1083 \\ S\left(\mathrm{cal} \mathrm{mol}^{-1} \mathrm{~K}^{-1}\right) & 211.890 & 208.613 \\ G & -1648.2378 & -1648.2074 \\ \text { ro point energy correction. } & & \end{array}$

$7.81(\mathrm{~m}, 22 \mathrm{H}, \mathrm{Ar}-\mathrm{H}), 4.86(\mathrm{~s}, 2 \mathrm{H},-\mathrm{N}-\mathrm{CH}-\mathrm{CH}-\mathrm{N}-),{ }^{13} \mathrm{C}$ $\operatorname{NMR}\left(\mathrm{CDCl}_{3}\right): \delta(\mathrm{ppm}) 168.0(-\mathrm{CH}=\mathrm{N}), 161.3(-\mathrm{C}-\mathrm{O})$, 118.9-138.7 (Ar-C); IR $\left(\mathrm{cm}^{-1}\right): 1621$.

Crystal structure Determination. The yellow prism crystal of the Schiff base compound (1S,2S)-1,2-diphenyl$N, N^{\prime}$-bis [(E)-2-hydroxynaphthalen-1-ylmethylidene] ethane1,2-diamine was mounted on a Rigaku Synergy Dualflex automatic diffractometer fitted with a Pilatus $300 \mathrm{~K}$ detector using $\mathrm{Cu} \mathrm{K} \alpha$ mirror-monochromatized $(\lambda=1.54178 \AA$, microfocus sealed Photon Jet X-ray tube) radiation at a temperature of $100.0(1) \mathrm{K}$. SHELXS, ${ }^{30}$ SHELXL, $^{31}$ and SHELXTL $^{32}$ programs were used for all the calculations. Atomic scattering factors were taken from International Tables for Crystallography. ${ }^{33}$ The Flack parameter was determined in the Parsons-Flack-Wagner extension ${ }^{21}$ using 1043 quotients. $^{34,35}$ Selected bond distances and dihedral angles are listed in Table 1, whereas intermolecular interactions and refinement details are given in Tables 2 and 3, respectively.

Hirshfeld Surface Analysis and Computational Measurements. The topological data analyses were made on $\mathbf{a}$
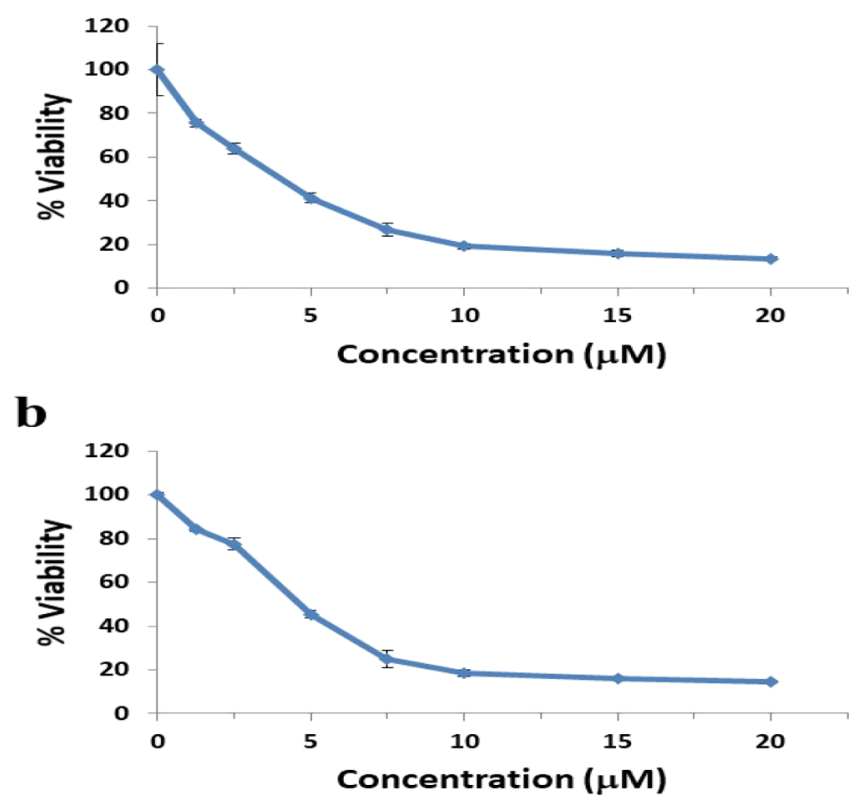

Figure 9. Cytotoxic activity of the compound. HT-29 (a) and SW620 (b) colorectal cancer cell lines were exposed to the indicated concentration of the compound for $24 \mathrm{~h}$. Cell viability was evaluated by MTT assay and results are expressed from experiments performed in triplicate as mean $\pm \mathrm{SD}$.

Crystal Explorer 17.5, ${ }^{36}$ whereas all DFT calculations were recorded on the Gaussian 09 software package ${ }^{37,38}$ by the B3LYP/6-31G $(\mathrm{d}, \mathrm{p})$ method. NBO analyses were recorded on the NBO 3.1 program. $^{39}$

Cell Culture. The HT-29 and SW620 human colorectal cancer cells were grown in RPMI medium (Thermo Fisher Scientific) supplemented with $10 \%$ heat-inactivated fetal bovine serum, $100 \mu \mathrm{g} / \mathrm{mL}$ streptomycin, 100 units $/ \mathrm{mL}$ penicillin, and $2 \mathrm{mmol} / \mathrm{L} \mathrm{L-glutamine.} \mathrm{Cells} \mathrm{were} \mathrm{cultured} \mathrm{in}$ a humidified $5 \% \mathrm{CO}_{2}$ incubator at $37^{\circ} \mathrm{C}$. A cell confluency of 70-80\% was achieved before their use for experiments.

Cell Viability Assay. The human colorectal cancer cells HT-29 and SW620 were grown in 96 well plates. After a period of $24 \mathrm{~h}$, cells were exposed to increasing concentrations from 1.25 to $20 \mu \mathrm{M}$ of the compound for $24 \mathrm{~h}$. Cells treated with an equal volume of dimethyl sulfoxide (DMSO) as the vehicle was used as control. Cell viability was assessed using tetrazolium dye MTT 3-(4,5-dimethylthiazol-2-yl)-2,5-diphenyltetrazolium bromide as described earlier. ${ }^{40}$ Briefly, after 24 $\mathrm{h}$ of incubation of the cells with the tested compound, freshly prepared $10 \mu \mathrm{L}$ of MTT ( $5 \mathrm{mM}$ ) solution was added and incubated further for $2 \mathrm{~h}$ at $37{ }^{\circ} \mathrm{C}$ in $5 \% \mathrm{CO}_{2}$. Finally, to dissolve the formazan crystals formed during MTT incubation, $100 \mu \mathrm{L}$ of DMSO was added and mixed well by pipetting. Absorbance of the solution was recorded at $540 \mathrm{~nm}$ in a microplate reader, whereas experiments were performed in triplicate for every concentration of the compound. The graph showed the mean with standard deviation (SD) of three independent experiments. $\mathrm{IC}_{50}$ values were calculated using the formula $y=m x+b$, where $m$ and $b$ indicate the slope and intercept calculated using Microsoft Excel 2010, respectively. 


\section{ASSOCIATED CONTENT}

\section{(5) Supporting Information}

The Supporting Information is available free of charge at https://pubs.acs.org/doi/10.1021/acsomega.0c03376.

H NMR spectrum, C NMR spectrum, and IR spectrum of the Schiff base compound, atom numbering of the optimized structure, and calculated geometric parameters, calculated natural charges, and $\mathrm{E}^{(2)}(\mathrm{kcal} / \mathrm{mol})$ values for the charge transfer interactions of the studied compound (PDF)

CCDC1889551 contains all crystallographic data and can be collected from the Cambridge Crystallographic Data Centre free of charge (CIF)

\section{AUTHOR INFORMATION}

\section{Corresponding Author}

Mohammad Azam - Department of Chemistry, College of Science, King Saud University, Riyadh 11451, Saudi Arabia; ○ orcid.org/0000-0002-4274-2796; Email: azam_res@ yahoo.com, mhashim@ksu.edu.sa

\section{Authors}

Saud I. Al-Resayes - Department of Chemistry, College of Science, King Saud University, Riyadh 11451, Saudi Arabia

Agata Trzesowska-Kruszynska - Institute of General and Ecological Chemistry, Lodz University of Technology, Lodz 90924, Poland

Rafal Kruszynski - Institute of General and Ecological Chemistry, Lodz University of Technology, Lodz 90-924, Poland; O orcid.org/0000-0003-1667-4379

Saied M. Soliman - Department of Chemistry, Faculty of Science, Alexandria University, Alexandria 21321, Egypt;

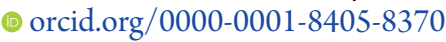

Ranjan K. Mohapatra - Department of Chemistry, Government College of Engineering, Keonjhar, Odisha 758002, India

Zahid Khan - Genome Research Chair, Department of Biochemistry, College of Science, King Saud University, Riyadh 11451, Saudi Arabia

Complete contact information is available at:

https://pubs.acs.org/10.1021/acsomega.0c03376

\section{Notes}

The authors declare no competing financial interest.

\section{ACKNOWLEDGMENTS}

The authors acknowledge the financial support through Researchers Supporting Project number (RSP-2020/147), King Saud University, Riyadh, Saudi Arabia.

\section{REFERENCES}

(1) Siegel, R. L.; Miller, K. D.; Jemal, A. Cancer statistics, 2016. CaCancer J. Clin. 2016, 66, 7-30.

(2) Konkankit, C. C.; Marker, S. C.; Knopf, K. M.; Wilson, J. J. Anticancer activity of complexes of the third row transition metals, rhenium, osmium, and iridium. J. Chem. Soc., Dalton Trans. 2018, 47, 9934-9974.

(3) Huang, R.; Wallqvist, A.; Covell, D. G. Anticancer metal compounds in NCI's tumor-screening database: putative mode of action. Biochem. Pharmacol. 2005, 69, 1009-1039.

(4) Lippert, B. Cisplatin: Chemistry and Biochemistry of a Leading Anticancer Drug; John Wiley \& Sons, 1999.

(5) Gao, C.-Y.; Qiao, X.; Ma, Z.-Y.; Wang, Z.-G.; Lu, J.; Tian, J.-L.; $\mathrm{Xu}$, J.-Y.; Yan, S.-P. Synthesis, characterization, DNA binding and cleavage, BSA interaction and anticancer activity of dinuclear zinc complexes. J. Chem. Soc., Dalton Trans. 2012, 41, 12220-12232.

(6) Lian, W.-J.; Wang, X.-T.; Xie, C.-Z.; Tian, H.; Song, X.-Q.; Pan, H.-T.; Qiao, X.; Xu, J.-Y. Mixed-ligand copper (II) Schiff base complexes: the role of the co-ligand in DNA binding, DNA cleavage, protein binding and cytotoxicity. J. Chem. Soc., Dalton Trans. 2016, 45, 9073-9087.

(7) Shokohi-Pour, Z.; Chiniforoshan, H.; Sabzalian, M. R.; Esmaeili, S.-A.; Momtazi-borojeni, A. A. Cobalt (II) complex with novel unsymmetrical tetradentate Schiff base (ON) ligand: in vitro cytotoxicity studies of complex, interaction with DNA/protein, molecular docking studies, and antibacterial activity. J. Biomol. Struct. Dyn. 2018, 36, 532-549.

(8) Ghorai, P.; Saha, R.; Bhuiya, S.; Das, S.; Brandão, P.; Ghosh, D.; Bhaumik, T.; Bandyopadhyay, P.; Chattopadhyay, D.; Saha, A. Syntheses of $\mathrm{Zn}$ (II) and Cu (II) Schiff base complexes using N, O donor Schiff base ligand: crystal structure, DNA binding, DNA cleavage, docking and DFT study. Polyhedron 2018, 141, 153-163.

(9) Abd El-Halim, H. F.; Mohamed, G. G.; Anwar, M. N. Antimicrobial and anticancer activities of Schiff base ligand and its transition metal mixed ligand complexes with heterocyclic base. Appl. Organomet. Chem. 2018, 32, No. e3899.

(10) Jing, C.; Wang, C.; Yan, K.; Zhao, K.; Sheng, G.; Qu, D.; Niu, F.; Zhu, H.; You, Z. Synthesis, structures and urease inhibitory activity of cobalt (III) complexes with Schiff bases. Bioorg. Med. Chem. 2016, 24, 270-276.

(11) Cozzi, P. G. Metal-Salen Schiff base complexes in catalysis: practical aspects. Chem. Soc. Rev. 2004, 33, 410-421.

(12) Katsuki, T. Unique asymmetric catalysis of cis- $\beta$ metal complexes of salen and its related Schiff-base ligands. Chem. Soc. Rev. 2004, 33, 437-444.

(13) Mandal, M.; Nagaraju, V.; Karunakar, G. V.; Sarma, B.; Borah, B. J.; Bania, K. K. Electronic, conjugation, and confinement effects on structure, redox, and catalytic behavior of oxido-vanadium (IV) and(V) chiral Schiff base complexes. J. Phys. Chem. C 2015, 119, 2885428870.

(14) Nindakova, L. O.; Lebed', F. M.; Zamazei, A. Y.; Shainyan, B. A. New C 2-symmetric optically active salen ligands and their cobalt (II) complexes. Hydridoborate reduction of prochiral $\mathrm{C}=\mathrm{O}$ and $\mathrm{C}=$ C bonds. Russ. J. Org. Chem. 2007, 43, 1322-1329.

(15) Irfanoglu, B.; Wolf, C. Circular dichroism sensing of chiral compounds using an achiral metal complex as probe. Chirality 2014, 26, 379-384.

(16) Shen, G.; Gou, F.; Cheng, J.; Zhang, X.; Zhou, X.; Xiang, H. Chiral and non-conjugated fluorescent salen ligands: AIE, anion probes, chiral recognition of unprotected amino acids, and cell imaging applications. RSC Adv. 2017, 7, 40640-40649.

(17) Groom, C. R.; Bruno, I. J.; Lightfoot, M. P.; Ward, S. C. The Cambridge structural database. Acta Crystallogr., Sect. B: Struct. Sci., Cryst. Eng. Mater. 2016, 72, 171-179.

(18) Desiraju, G. R.; Steiner, T. The Weak Hydrogen Bond: In Structural Chemistry and Biology; Oxford University Press, 1999.

(19) Bernstein, J.; Davis, R. E.; Shimoni, L.; Chang, N.-L. Patterns in hydrogen bonding: functionality and graph set analysis in crystals. Angew. Chem. 1995, 34, 1555-1573.

(20) Kruszynski, R.; Sierański, T. Can stacking interactions exist beyond the commonly accepted limits? Cryst. Growth Des. 2016, 16, 587-595.

(21) Nakamoto, K. Infrared and Raman Spectra of Inorganic and Coordination Compounds; John Willey and Sons Inc.: New York, 1986.

(22) Azam, M.; Al-Resayes, S. I. Phenoxy-bridged binuclear Zn (II) complex holding salen ligand: Synthesis and structural characterization. J. Mol. Struct. 2016, 1107, 77-81.

(23) Foresman, J.; Frish, E. Exploring Chemistry; Gaussian Inc.: Pittsburg, USA, 1996.

(24) Kosar, B.; Albayrak, C. Spectroscopic investigations and quantum chemical computational study of (E)-4-methoxy-2-[(ptolylimino) methyl] phenol. Spectrochim. Acta, Part A 2011, 78, 160167. 
(25) Koopmans, T. Ordering of wave functions and Eigen energies to the individual electrons of an atom. Physica 1933, 1, 104-113.

(26) Parr, R. G. Density Functional Theory of Atoms and Molecules; Oxford University Press: New York, USA, 1989.

(27) Parr, R. G.; Szentpály, L. v.; Liu, S. Electrophilicity index. J. Am. Chem. Soc. 1999, 121, 1922-1924.

(28) Joe, I. H.; Kostova, I.; Ravikumar, C.; Amalanathan, M.; Cîntǎ Pînzaru, S. Theoretical and vibrational spectral investigation of sodium salt of acenocoumarol. J. Raman Spectrosc. 2009, 40, 10331038.

(29) Sebastian, S.; Sundaraganesan, N. The spectroscopic (FT-IR, FT-IR gas phase, FT-Raman and UV) and NBO analysis of 4Hydroxypiperidine by density functional method. Spectrochim. Acta, Part A 2010, 75, 941-952.

(30) Sheldrick, G. M. SHELXT- Integrated space-group and crystalstructure determination. Acta Crystallogr., Sect. A: Found. Adv. 2015, $71,3-8$.

(31) Sheldrick, G. M. Crystal structure refinement with SHELXL. Acta Crystallogr., Sect. C: Struct. Chem. 2015, 71, 3-8.

(32) Sheldrick, G. M. A short history of SHELX. Acta Crystallogr., Sect. A: Found. Crystallogr. 2008, 64, 112-122.

(33) Prince, E.; Wilson, A. J. C. International Tables for Crystallography; Kluwer Academic Press, 2004; Vol. 100.

(34) Parsons, S.; Flack, H. D.; Wagner, T. Use of intensity quotients and differences in absolute structure refinement. Acta Crystallogr., Sect. B: Struct. Sci., Cryst. Eng. Mater. 2013, 69, 249-259.

(35) Singh, R. N.; Kumar, A.; Tiwari, R. K.; Rawat, P.; Gupta, V. P. A combined experimental and quantum chemical (DFT and AIM) study on molecular structure, spectroscopic properties, NBO and multiple interaction analysis in a novel ethyl 4-[2-(carbamoyl) hydrazinylidene $]-3$, 5-dimethyl-1H-pyrrole-2-carboxylate and its dimer. J. Mol. Struct. 2013, 1035, 427-440.

(36) Turner, M.; McKinnon, J.; Wolff, S.; Grimwood, D.; Spackman, P.; Jayatilaka, D.; Spackman, M. CrystalExplorer17; University of Western Australia, 2017.

(37) Frisch, M.; Trucks, G.; Schlegel, H. B.; Scuseria, G. E.; Robb, M. A.; Cheeseman, J. R.; Scalmani, G.; Barone, V.; Mennucci, B.; Petersson, G. Gaussian 09, Revision d. 01; Gaussian Inc.: Wallingford CT, 2009.

(38) Dennington, R.; Keith, T.; Millam, J. GaussView; Semichem Inc.: Shawnee Mission, KS, 2009.

(39) Reed, A. E.; Curtiss, L. A.; Weinhold, F. Intermolecular interactions from a natural bond orbital, donor-acceptor viewpoint. Chem. Rev. 1988, 88, 899-926.

(40) Azam, M.; Al-Resayes, S. I.; Soliman, S. M.; TrzesowskaKruszynska, A.; Kruszynski, R.; Khan, Z. A (salicylaldiminato) Pt (II) complex with dimethylpropylene linkage: Synthesis, structural characterization and antineoplastic activity. J. Photochem. Photobiol., B 2017, 176, 150-156. 